\title{
THE ROLE OF COMPLIMENT ON THE BUYING-SELLING TRANSACTION AT TRADITIONAL MARKET
}

\author{
Fahmi Reza Alfani ${ }^{1}$, Sukarno ${ }^{2}$, Akhmad Haryono ${ }^{3}$ \\ ${ }^{1}$ Faculty of Humanities, Jember University, Indonesia \\ ${ }^{2}$ Faculty of Humanities, Jember University, Indonesia \\ ${ }^{3}$ Faculty of Humanities, Jember University, Indonesia \\ Email: ${ }^{1}$ rezaalfanifahmi@gmail.com, ${ }^{2}$ sukarno.sastra@unej.ac.id, \\ 3aharyono.sastra@unej.ac.id
}

Submitted: 17-01-2021 Review: 12-03-2021 Accepted: 19-03-2021

DOI:https://doi.org/10.22202/tus.2021.v7i1.4790

\begin{abstract}
A compliment plays an important role to the communication because it gives a happy effect for the speaking partner. In the interaction context, a compliment is often used as the communication strategy to achieve the particular interest. The compliment has the important role on the buying-selling transaction at traditional market. This research aims to describe the important role of the compliment on the success of the buying-selling transaction in the traditional market. This research used qualitative descriptive to analyze the compliment used by seller and buyer. The data were collected through conversation using a hidden recorder and taking some notes. The result of the study showed that the compliment has the four roles on the success of buying-selling transaction in the traditional market such as at Pasar Waru, Kabupaten Sidoarjo. Those were the compliment as a means of calling the potential buyer, bargaining process, convincing the buyer, and building the small talk.
\end{abstract}

\section{Keywords: compliment, communication strategy, buying-selling transaction}

\section{INTRODUCTION}

Each individual tries to maintain harmony in communicating with the speech partner. The act of giving compliment is often used so that communication activities can be harmonious. The compliment is a speech act either implicitly or explicitly to give an appreciation to someone other than the speaker, usually that person is aimed at some goodness (ownership, character, abilities, etc.) which the speaker and listener consider positively (Holmes, 1988). The compliment is used to negotiate a relationship of solidarity with speech partners so that people feel happy (Herbert, 1989).

The compliment can provide a pleasant feeling so that it can show friendly feelings and build solidarity with speech partners (Kingkin, 2014). The 
compliment can also be called a communication strategy that acts as a confounder in a conversation. In the social interaction, the compliment utterance has an important role because it can stimulate the effect of good feeling for the speech partners. The context of this good feeling has a correlation with human nature, namely humans will have a happy feeling when they are praised.

In the context of interaction, the compliment is often used as a communication strategy to achieve certain desires. Buyers and sellers often use compliments as a communication strategy to reach an agreement on the desired buying-selling transaction. A simple definition of buying-selling transactions is an activity to sell or buy goods or services, either directly or indirectly (online via ecommerce).

In the practice, buying-selling transaction occurs when the seller and the buyer reach an agreement on the price of a good or service. To reach an agreement, the process of bargaining the price of goods or services often occurs, especially in buying-selling transactions directly. Communication activities in buying-selling transactions like this will be further discussed and disclosed in this study by considering the behavior of the perpetrators in carrying out the buyingselling transactions, the communication strategies used, and the interests in them.

Buying-selling transaction activities can occur anywhere and anytime. In modern age, buying-selling transaction is not only done in person or face to face but can be done by email, social media, and telephone. However, in general, buying-selling transactions that often occur are carried out person or face to face, such as in a traditional market that provide daily necessities.

In the traditional market, the causes of successful buying-selling transactions are not only focused on affordable prices, but there can also be other causes, such as the use of the magic spell to sell goods, and the building of emotional relationship with a good communication that can make buyers prefer certain sellers as customers. Buyers often buy goods they need at the shop which according to them which have a good communication, such as the seller gives compliments for them when the buyer and the seller are going on process of 
buying-selling transaction. Examined more deeply, the compliment has an important role to attract the sympathy of potential buyers and reach an agreement in buying-selling transactions.

Some Previous studies related to the compliment has been examined, among others, by Holmes (1986) who examined the compliment on the use of English used by students in New Zealand. The result of study explained that women give and receive more compliments. Then, the compliment is often used among the woman to another woman. To another study, Manipuspika and Sudarwati (2016) discussed utterances in responding the compliments used by lecturers on the campus. The result of study disclosed that some lecturers prefer using L1 (first language) to L2 (second language) in an English, however they have a competence in the English field when they taught it in the classroom. Furthermore, Razi (2012) examined to give and respond the compliment made by Australian and Iranian Persian English speakers. The result of study disclosed that there were the differences between Australian and Persian English speakers. That difference was signed by Australian English speakers were oftener responding the compliments by a way of accepting the compliment rather than Persian English speakers. Whereas, Persian English speakers were oftener responding the compliment by a way of rejecting and avoiding the compliment. Furthermore, Rose (2001) examined compliments and responding compliments in some films at America. The result of study explained that the concept of gender influenced compliments and responding compliments. The woman often gave and received the compliment than the man. The study identified that the category of acceptance often appeared in that films.

Above previous studies have the contribution for this study. The previous studies help to apply the strategy to observe the situation that will be researched. Furthermore, the concept of collecting and analyzing data in those previous studies is used in this study. Those previous studies also help to give the knowledge regarding the compliments that can make easier to apply the theory of compliment in this study. 
As previous studies related to the research about traditional markets, among others, by Wahyuni dan Afifah (2016) who researched the comparison of politeness done by seller and buyer in the traditional market and modern. The result of study showed that the process of interaction or communication used seller and buyer paying attention to some aspects, those are who speaks to whom, what speaks about, and where in those settings. To another research, Astuti (2014) researched about cooperative principle on buying-selling transactions in traditional market, Perumnas Tlogosari. The result of study showed that the seller and the buyer in that traditional market have obeyed and violated cooperative principle. Furthermore, Nurmiah (2014) researched implicature used by seller and buyer when they made buying-selling transaction. The data were taken on the traditional market in Palu City. The result of study showed that the seller and the buyer often used the implicature when they made buying-selling transactions.

Above previous studies have the contribution for this study. The previous studies help to apply the strategy to observe situation that will be researched, especially in the traditional market. Furthermore, the previous studies also give the knowledge regarding buying-selling transactions in the traditional market, such as the characteristics of the seller and buyer when they make a transaction.

Based on the previous studies, there has been no research that discusses the compliment on buying-selling transactions in traditional markets by highlighting the role of the compliment in buying-selling transaction processes. Therefore, this study aims to determine the communication strategies that encourage sellers and buyers to use the compliment utterances to achieve certain desires, such as attracting the sympathy of potential buyers, and reaching a price agreement in buying-selling transactions for goods or services.

\section{METHODS}

This research was a qualitative research. According to Bogdan and Taylor (in Moleong, 2014), a qualitative approach was a research procedure that produces descriptive data in the form of written or spoken words from people and 
observable behavior. The qualitative approach had the objective that the researcher could describe the empirical reality behind the use of compliment utterances in buying-selling transactions at traditional markets detail and thoroughly. Qualitative research described data in the form of words or pictures rather than numbers or statistics (Ary et al, 2013). Therefore, this study would present data in the form of utterances or words.

The data were taken at Waru Market which was a traditional market in Waru District, Sidoarjo Regency. The subjects in this study were people involved in buying-selling transactions at Waru Market, namely sellers and buyers. The data in this study were utterances containing compliments in Javanese. The reason why this study took data in Javanese because the majority of the subjects studied used Javanese language speech when they made buying-selling transactions. This research used the observing method of engaging proficiently and taking the notes (Sudaryanto, 2015), in which researchers are directly involved in the use of compliment utterances. Then, the data were collected by recording and taking the notes.

After the data were recorded and taken the notes, data transcription was carried out, namely copying the data in the form of notes and recording it into written form. As explained by Haryono (2015), the data that had been collected by engaging with a recording device were transcribed into written form. Then, data analysis were presented with the classification of the role of compliment utterance on the success of buying-selling transactions at Waru Market.

\section{FINDING AND DISCUSSION}

The compliment utterances have four roles on the success of buyingselling transactions, namely the compliment utterance as a means of calling potential buyers, for the bargaining process, to convince the buyers, and to build the small talk.

\section{The compliment utterance as a means of calling potential buyers}


The data were taken from buying-selling activities when the seller calls a prospective the buyers. The following are the compliments that serve to address potential buyers:

\section{Chicken Meat Shop}

Context: The seller attracts the sympathy of potential buyers by calling him.

Seller: wong ayu, ayame, wong ayu

'Pretty woman, the chicken, pretty woman'

The above conversation fragment shows that the seller gives a compliment utterance to the prospective buyer marked with the word wong ayu 'pretty woman'. The compliment has a function as a substitute for the greeting. The greeting wong ayu 'pretty woman' uttered by the seller in the above part of the conversation is a compliment to call prospective buyers.

The use of the greeting wong ayu 'pretty woman' does not mean that the seller admires the face of the prospective buyer but the greeting wong ayu 'pretty woman' here serves as a strategy to attract sympathy from potential buyers. The seller feels the use of the greeting wong ayu 'pretty woman' to have the meaning of compliment that attracts potential buyers to stop by and even buy the seller's merchandise.

\section{Vegetable Shop}

Context: The seller attracts the sympathy of potential buyers by calling him.

Seller: sayangku 'my dear'

golek opo? 'What are you looking for?'

Buyers: sawi, cambah rong ewu tomat tigang ewu ning sawi

'Miss, I would like to buy mustard greens and sprouts two thousands, the tomatoes three thousand'

The above conversation fragment shows that the seller gives the compliment to the prospective buyer marked with the word sayangku 'my dear'. The compliment has a function as a substitute for the greeting. The greeting sayangku 'my dear' which is spoken by the seller in the above part of the conversation is a compliment to summon potential buyers. The greeting sayangku 'my dear' is a greeting of affection that aims to call prospective buyers with 
expressions of affection so that buyers stop by at their shop. The use of the word sayangku 'my dear' in this compliment also serves as a strategy to attract sympathy and build a harmonious relationship so that buyers buy the seller's merchandise.

The use of the word sayangku 'my dear' as a greeting word is addressed to buyers who are generally Javanese. For buyers, the greeting sayangku 'my dear' means affection. This makes prospective buyers interested in buying the seller's merchandise. The choice of the word sayangku 'my dear' spoken by the seller is a special attraction for prospective buyers because the speech sounds polite and full of affection, as if the seller spreads affection for the prospective buyers. The use of a polite greeting has its own charm for prospective buyers to simply stop by, see, and even buy the seller's merchandise.

\section{Fruit shop}

Context: the seller greets the buyer and compliments the bracelet worn by the buyer.

Seller: ji, masyaAlloh gelange kromyong ji, tambah ayu ngunu ji

“ $J i$, My God. You wear the bracelet very much ji. You get prettier like that.'

Buyer: pisan pisan tak gawe 'I use it occasionally'

Seller: golek kelengkeng a ji? niki ji, kelengkenge tigang doso mawon ji

'are you looking for longan Ji? This is it Ji, the longan is only thirty ji'

Buyer: (the buyer hands over the money)

iyo wes, kelengkenge 2, 'Yes, I buy two longans'

The above conversation fragment shows that the seller gives a compliment to the buyer, marked with the word $J i$ (Haji is the greeting for people who have performed Hajj). Ji's compliment has a function as a greeting to attract the sympathy of potential buyers. Haji is one of the pillars of Islam that Muslims must be fulfilled for those who are able. Indonesians who have performed this worship will get the title of Haji in the community. This title is given as a sign of 
appreciation for those who have fulfilled it. Therefore, the title is said to aim to appreciate people who have fulfilled it.

After the seller said Ji's greeting, then the seller said the gelange kromyong 'you have a lot of bracelets' and tambah ayu 'getting more beautiful'. The compliment of gelange kromyong 'the bracelet belongs to you very much' means that the gold bracelet owned by the buyer is very luxurious and really attracts the attention of others when they see it. Gold itself is believed to be a symbol of luxury when a woman wears it. Women who wear them are often identified with people who have a lot of wealth. Then, the compliment utterance tambah ayu 'getting more beautiful' is the effect of the buyer wearing the gold bracelet. Therefore, the seller expressed the compliment because the seller believed that the buyer looked beautiful when wearing a lot of gold bracelets.

The compliment strategy used by this seller makes potential buyers stop by the fruit shop. According to buying-selling transaction conversation above, it shows that the prospective buyer is pleased with the compliment. This can be seen the utterance pisan pisan tak gawe 'occasional use' which shows that prospective buyers receive the compliment. Then, the seller offers the merchandise to the buyer. Then, the buyer buys what the seller has offered to buy. This shows that the compliment utterance is in the form of greetings and utterances that contain an assessment of the appearance of the buyer to make buyers interested in shopping at the seller's shop.

\section{The Compliment Utterance As A Means Of Bargaining Process}

Data were taken from the buying-selling activities when the seller and the buyer are bidding in the shop. The following are the compliments that have the function as a process of bargaining for goods:

\section{Fruit shop}

Context: buyers and sellers are in the process of bargaining for longan fruit.

Buyer: bu, kelengkenge pintenan ? 'madam, how much does the longan fruit cost?' 
Seller: telu telu mbak 'thirty three thousand, miss'

Buyer: gak oleh kurang ta bu? 'Could you go lower, madam?'

Seller: gak oleh wong ayu 'I could not down that price, pretty woman'

Buyer: tigo, wolung puluh bu, 'How could be there items at eighty thousand, madam?'

Seller: sangang puluh iyo, wong ayu? 'How about ninety thousand, pretty woman?'

Buyer: (the buyer hands over the money to the seller)

nggih pun 'yes, I will just take it'

Seller: (seller handed over the fruit ordered by the buyer)

suwun wong ayu 'thank you the pretty woman'

Buying-selling transaction conversation above shows that the buyer wants to get a price discount for longan fruit. However, the seller refused the request from the buyer to reduce the price of the longan fruit.

The seller gives the compliment utterance to the buyer by using wong ayu 'beautiful woman'. The compliment is used by the seller as the rejection strategy. The rejection strategy is proven to make the buyer feel less offended and may not even buy the fruit. However, in the above case, the buyer continues to buy longan even though the buyer does not get a price discount.

\section{Fruit shop}

Context: buyers and sellers are in the process of bargaining against the fruit and the seller praises the buyers' children.

Seller: sak kilo luweh setengah sepuluh ewu ae, pinter arek ayu ngewangi ibuk e nang pasar, iyo ngunu nang pasar 'one kilogram over half ten thousand, smart beautiful girl helped her mother to the market, so as to market'

Buyer: niki ning 'it's ning' (handing over the money) matur suwun 'thank you'

Seller: sami sami mbak. 'you're welcome miss' 
The conversation shows that the buyer does not bid on the price of the fruit to be purchased. The conversation fragment also shows that after the seller fixes the price of the fruit that has been chosen by the buyer, the seller gives a compliment for buyer's daughter directly with the word pinter 'smart' and arek ayu 'beautiful girl'. The word pinter, 'smart', actually means someone who has intelligence. Meanwhile, arek ayu 'beautiful girl' means a woman who has a beautiful face. In the context of the compliment utterance above, the two compliment utterances have the meaning of a unity which emphasizes the side of personal goodness. So, the seller uses the compliment as a sign of appreciation for the personal kindness that the girl has because she has helped her mother shop at the market.

The interesting part_of that compliment is that the seller uses it when he has set the price for the fruit. Then, the buyer agrees to the price without him bidding on the price of the fruit. It can be perceived that compliment utterance aims to make the buyer feel comfortable in buying-selling transaction process so that he does not bid on the price of the fruit. The compliment above also aims to get buyers to shop again and become a customer at the shop.

\section{THE COMPLIMENT UTTERANCE AS A MEANS OF CONVINCING THE BUYER}

Data were taken from buying-selling transaction in the shop when the seller convinces his merchandise to the buyer. The following are the compliment utterances that have a function to convince the buyer to sell the merchandise:

\section{Fruit shop}

Context: the seller offers the buyer a taste of his wares.

Seller: sampean coba ning lak legi 'Miss, you try it. This is sweet' arek ayu kene lo 'beautiful girl come here'

Buyer: (buyer chooses oranges to weigh)

yo ning 'yes miss' 
The conversation fragment above shows that the seller tries to convince the buyer that the fruits have good qualities. The strategy used by the seller is by giving a good assessment of the fruit's her merchandises. This can be seen the utterance of sampean coba ning lak legi 'Miss, you try it. This is sweet'. The word legi 'sweet' is a compliment to express the taste of the orange. The conversation piece above shows that the seller is inviting the buyer to testify the taste of the citrus fruit. The context for the word coba 'try' is that the seller allows the buyer to taste the citrus fruit. Then, the buyer responds by tasting the citrus fruit immediately and saying yo ning 'yes miss'. This utterance means that the citrus fruit has a sweet taste.

\section{Fruit Shop}

Context: the seller offers the buyer to taste the oranges and the buyer agrees to taste the oranges.

Seller: sampean incip wong ayu lak legi 'You can taste it first, pretty girl. It must be sweet'

Buyer: (buyer tasted the orange)

enggih bu legi. Apele sampean pundut no seng apik bu

'yes it is sweet, madam. Please, take the apples are good, madam'

The data above showed that fruit sellers often use a sales strategy in which the seller asks the buyer to taste the fruit before he buys it. This is done by the seller because the seller feels that most of the buyers do not know the knowledge for the fruits. Therefore, the sales strategy is used by the seller to convince buyers. That compliment has the same function as the previous data, which is to convince the buyer that the fruits, as the merchandise, have a good quality and are worth for buying.

\section{The Compliment Utterance As A Means Of Building Small Talks}

Data were taken from buying-selling transaction activities in the shop when sellers and buyers interact with small talk that has nothing to do with the buying-selling transaction process. Those are the tributes that work for small talk: 


\section{Beef shop}

Context: Buyers and sellers already know each other before there is buyingselling transaction in beef shop. In the buying-selling transaction, the seller comments on the body shape what the buyer has.

Buyer: de 'uncle'

niki 'this' (giving shopping notes to seller)

Seller: oke 'ok' (preparing ordered items)

tak delok delok awak mu kok tambah six pack ngunu

'I see that you have the body more six pack'

Buyer: iyo ta de? kakean angkat angkat

'Are you sure uncle? I often lift heavy goods'

Seller: amit 'excuse me' (give the buyer the order)

pengen aku iki 'I would like to be you',

Buyer: niki 'this' (hand over money)

Seller: susuk sepuluh ewu. 'here is the change of ten thousand'

suwun 'thank you'

Buyer: sami sami de 'you're welcome, uncle'

The situation in this part of the conversation shows that the seller and the buyer are familiar before there is buying-selling transaction and even the buyer is a customer of the seller. The word oke 'ok', which has a context in which the seller responds to the request of the goods from the buyer, which then the seller prepares the ordered goods. When the seller prepares it, the seller also tries to get the buyer to talk about the body shape what the buyer has. That small talk about the body shape does not relate to the buying-selling transaction.

The above conversation fragment shows that the seller gives compliments for the buyer regarding his physical appearance which is indicated by the word tambah six pack 'adding six pack'. This refers to the athletic body shape of the buyer. The word six pack itself is adopted from the English idiom which means it is a muscle shape that resembles the arrangement of six boxes on the stomach. The word tambah 'more' before the word six packs indicates that there is a 
physical activity process that has been carried out by the buyer to achieve an athletic body shape.

Small talk is used by the seller so that the buyer does not feel bored during the process of waiting for goods. The compliment used by the seller is intended as a means of building small talk in the buying-selling transaction process. Giving compliments on the activities carried out by buyers is one of the topics that can be discussed when the seller wants to build interactions in buying-selling transactions to buyers. Therefore, the compliment utterance serves as a means of building a relationship of intimacy and comfort in buying-selling interactions.

\section{Chicken meat shop}

Context: buyers and sellers already know each other before the sale and purchase transaction. In the sale and purchase transaction, the seller discusses the motorbike owned by the buyer.

Buyer: pak 'sir'

telung kilo ae pak 'I just buy it three kilos, sir'

Seller: ndengaren 'it is unusual'

Buyer: gowo siomay rodok akeh 'I brings more dumplings'

Seller: oalah 'oalah'

Buyer: sepeda ae sampean wes kenek ngunu lo.mbok benak no nangendi?

'your motorcycle can be ridden that way. where did you fix it?'

Seller: tak ndandani dewe pak 'I fix it myself, sir'

Buyer: hebat ngunu! 'that's great!'

Seller: mboh, tak otak atek kok kenek. wes ta?

'I didn't know, suddenly I can fix it. already?'

(seller submits ordered goods)

Buyer: wes. ayo desek yo pak 'already. I'll go ahead sir'

(buyer hands over money)

Seller: iyo 'yes'

The utterance hebat ngunu 'that's great' indicates that the seller is giving the compliment for the buyer on his ability to repair the motorbike. The 
compliment expressed by the buyer is a form of admiration addressed to the seller because the seller has succeeded in repairing his motorcycle even though the seller is not an expert in the mechanic field. This can be identified when a seller responds to a compliment from a buyer with a statement that he doesn't mind why he says 'I didn't know suddenly I can fix it'. This statement means that the seller repaired his motorbike without any standard procedure as a mechanic expert in repairing motorbikes and even he was not sure if he was successful in repairing it.

\section{Chicken meat shop}

Context of buyers and sellers is that they already know each other before the sale and purchase transaction process and may even be neighbors. This can be proven when they discuss food.

Seller: mbak 'mistress'

Buyer: bu, ayame setengah, swiwine sekawan ewu

'Madam, I buy a half chicken and chicking wings at four thousand

Seller: mbak pancen wenak masakane sampean, wingi oleh teko tahlilan langsung digeruduk entek

'Miss, your cooking is indeed delicious, yesterday you got it from the tahlilan ( ritual religion in Islam). The food was immediately finished'

(the seller prepares orders from the buyer)

Buyer: nggih ngoten bu, masak ane kulo

'yes madam, that is my cooking'

Seller: limolas ae 'it is just fifteen thousand'

(The seller submits the order to the buyer)

Buyer: matur suwun lo bu 'thank you madam'

(the buyer hands over the money)

The data above shows that the seller gives the compliment for the buyer's ability to cook. It can be known by the utterance wenak masakane sampean 'your cooking is indeed delicious'. This statement shows that the seller like the food that the buyer has cooked. The compliment utterance aims to show appreciation for the ability in the cooking field. This ability in daily activities is usually done by 
fellow women. Even though cooking is a skill that is usually owned by women, the compliment for this ability is still appeared when the woman gives the compliment to another woman. Therefore, the compliment utterance regarding the ability in the cooking field in the data above are aimed at maintaining solidarity relations between people.

\section{CONCLUSION}

The compliment has an important role in buying-selling transaction process. Sellers often use compliments as a communication strategy to attract sympathy for potential buyers. This study identifies that the compliment utterance has four roles in success in terms of buying-selling transactions at Market Waru as traditional market in Sidoarjo Regency, namely, the compliment utterance as a means of calling potential buyers, bargaining process, convincing the buyers, and building a small talk.

The compliment utterance to call the potential buyer, that is, the seller uses a complimented greeting to call the potential buyers. This is done so that they step in to the seller's shop. The compliment utterance for bargaining process, namely the seller uses the compliment as a form of seduction so that the buyer does not bid on a price that the seller does not want, and the compliment utterance serves to prevent the buyer from being offended when the seller refuses the bid price from the buyer. The compliment to convince the buyer, that is, the seller gives the compliment to his merchandise if it has a good quality and is worth for buying. The compliment as small talk, where the seller wants to build an atmosphere of interaction, being comfortable and not get bored when the buyer waits for the seller's order to be prepared. Therefore, the compliment can be used as a means of building a small talk. Furthermore, the compliment utterance as a small talk has a function to maintain a familiarity and comfort in buying-selling interactions. 


\section{REFERENCES}

Ary, D., Jacobs, L. C., Sorensen, C., \& Razavieh A. (2013). Introduction to research in education. $9^{\text {th }}$ Ed., Wadsworth: Cengage Learning.

Astuti, S. P. (2014). Prinsip Kerjasama dalam Wacana Jual Beli di Pasar Tradisional Perumnas Tlogosari Semarang. Jurnal Humanika, 20 (2), pp. 67-73.

Haryono, A. (2015). Etnografi Komunikasi: Konsep, Metode, dan Contoh Penelitian Pola Komunikasi. Jember: UPT Penerbitan UNEJ.

Herbert, R. K. (1989). The ethnography of English compliment and compliment responses: a contrastive sketch. Dalam W. Oleksy Ed, Contrastive Pragmatics. Amsterdam/Philadelphia: John Benjamins Publishing company.

Holmes, J. (1986). Compliments And Compliment Responses In New Zealand English. Antropological Linguistics, 28 (4), pp. 485-508.

Holmes, J. (1988). Paying Compliments: A Sex-Preferential Politeness Strategy. Journal of Pragmatics, 12 (4), pp. 445-465.

Kingkin, P. K. (2014). Memuji dan Merespon Pujian Dalam Bahasa Indonesia. Tesis. Universitas Gadjah Mada.

Manipuspika, Y. S. \& Sudarwati, E. (2016). Compliment Responses by Indonesia Lectures of English. Sosiohumanika, 9 (1), pp. 105-116.

Moleong, L. J. (2014). Metodologi Penelitian Kualitatif. Bandung: PT. Remaja Rosdakarya.

Nurmiah. (2014). Implikatur Percakapan dalam Transaksi Jual Beli di Pasar Tradisional di Kota Palu. Multilingual, 13 (2), pp.196-207.

Razi, N. (2013). A contrastive study of compliment responses among Austrlian English and Iranian Persian speakers. Procedia - Social and Behavioral Sciences, 70, pp. 61-66.

Rose, K. R. (2001). Compliments and compliment responses in film: Implications for pragmatics research and language teaching. International review of Applied Linguistics in Language Teaching., 39 (4), pp. 309-326.

Sudaryanto. (2015). Metode dan Aneka Teknik Analisis Bahasa: Pengantar Penelitian Kebudayaan secara Linguistis. Yogyakarta: Duta Wacana University Press. 
Wahyuni, L. D. \& Afifah, N. (2014). Perbandingan Kesantunan di Pasar Tradisional dan Pasar Modern. Prosiding Prasasti, pp. 78-83. 